Check for updates

Cite this: RSC Adv., 2017, 7, 37771

Received 9th June 2017

Accepted 20th July 2017

DOI: 10.1039/c7ra06482a

rsc.li/rsc-advances

\section{Targeted isolation of sulfur-containing metabolites
from Lsr2-deletion mutant strain of Streptomyces \\ Targeted isolation of sulfur-containing metabolites
from Lsr2-deletion mutant strain of Streptomyces roseosporus $\dagger$}

\author{
Lina Deng, ${ }^{a}$ Rui Wang, ${ }^{a}$ Guowei Wang, ${ }^{\text {*a }}$ Mingxu Liu, ${ }^{a}$ Guojian Liao, ${ }^{a}$ Zhihua Liao ${ }^{b}$ \\ and Min Chen (iD *a
}

\begin{abstract}
Deletion of the Lsr2 gene in Streptomyces roseosporus up-regulated silent gene clusters and produced new secondary metabolites. An ultra-performance liquid chromatography quadrupole time of flight mass spectrometry (UPLC-QTOF-MS/MS) method was used to analyze metabolites of the mutant and wildtype strains, and recognize previously unreported sulfur-containing compounds based on their molecular formulas and fragmentation ions. The targeted isolation of unidentified compounds afforded six new sulfur-containing compounds, pyrismycins A-F (1-6), together with seven known analogues 713. Their cytotoxic effects were evaluated using four clinically relevant human cancer cell lines, gastric carcinoma SGC7901, breast carcinoma MDA-MB-231, lung carcinoma A549 and hepatocellular carcinoma HepG2. Compound 7 exhibited the most potent cytotoxicity with $I_{50}$ values of $1.7,5.8$ and $6.3 \mu \mathrm{M}$ against the SGC7901, HepG2 and MDA-MB-231, respectively.
\end{abstract}

\section{Introduction}

Streptomyces produce a wealth of chemically diverse secondary metabolites with a wide range of biological activities. These have been used as antibacterial, antifungal, anticancer, antiparasitic and immunosuppressive agents. ${ }^{1}$ Sulfur-containing metabolites are common across the Streptomyces kingdom and constitute a family of natural products which play an important role in the health care for humans., ${ }^{2,3}$ Among the top 200 best-selling drugs in the current drug market, about $86 \%$ of them are sulfur and/or nitrogen containing compounds. ${ }^{4}$

Microbial genomics and bioinformatics analysis has revealed that many microorganisms have far greater potential to produce specialized metabolites than have been discovered by classic screening-based methods. Bioinformatics analysis of the genome of $S$. roseosporus disclosed 25 gene clusters, which include 14 NRPS or PKSs, three for terpene

${ }^{a}$ College of Pharmaceutical Sciences, Key Laboratory of Luminescent and Real-Time Analytical Chemistry, Ministry of Education, Southwest University, Chongqing 400715, P. R. China.E-mail: mminchen@swu.edu.cn;wangguowei1987@163.com ${ }^{b}$ School of Life Sciences, Southwest University, Chongqing 400715, P. R. China $\dagger$ Electronic supplementary information (ESI) available: ESI Experimental section; Table S1 (sulfur-containing metabolites detected and characterized in 4 Srlsr2 strain by UPLC-QTOF-MS and HR-MS/MS analysis); Table S2 (cytotoxic activities of 1-13 isolated from the 4 Srlsr2 strain of $S$. roseosporus); Fig. S1 (HR-MS/MS spectra and proposed fragmentation pathway of peaks 17 and 18 (1 and 2)); Fig. S2 (HPLC guided isolation of sulfur-containing metabolites); Fig. S3 (X-ray crystal structure of 10); NMR and HRMS spectra of compounds 1-6. CCDC 1533762. For ESI and crystallographic data in CIF or other electronic format see DOI: $10.1039 / \mathrm{c} 7 \mathrm{ra} 06482 \mathrm{a}$ biosynthesis, three for siderophore, two for bacteriocin, one ectoine, and two other gene clusters. ${ }^{5}$ Relative to the limited number of secondary metabolites isolated from $S$. roseosporus, many gene clusters in this bacteria seemingly are not<smiles>COc1cc(-c2cccnc2)nc(/C=N/O)c1OC</smiles><smiles></smiles>

$\mathrm{R}$

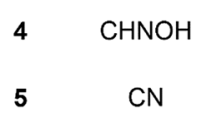<smiles>[R]c1nc(-c2ccccn2)cc(OC)c1[R]</smiles>

$\mathrm{R}_{1}$

$2 \mathrm{SCH}_{3}$

$3 \quad \mathrm{SCH}_{3}$

$6 \mathrm{SOCH}_{3}$ $\mathrm{CH}_{2} \mathrm{OH}$

$7 \quad \mathrm{SCH}_{3}$ $\mathrm{CHNOH}$

$8 \quad \mathrm{SCH}_{3}$ $\mathrm{CH}_{2} \mathrm{OH}$

$9 \mathrm{SCH}_{3}$

$\mathrm{CN}$

$10 \mathrm{SCH}_{3}$

$\mathrm{CH}_{2} \mathrm{NHCOCH}_{3}$

$11 \mathrm{SOCH}_{3}$

$\mathrm{CHNOH}$

$12 \mathrm{SOCH}_{3}$

$\mathrm{CN}$

13
$\mathrm{H}$

$\mathrm{CHNOH}$
Fig. 1 Chemical structures of compounds 1-13 
expressed, implying that there is additional metabolic potential in this species.

A number of approaches have been developed to activate and up-regulate silent or cryptic gene clusters to produce new compounds. ${ }^{6,7}$ Lsr2 is a small nucleoid-associated protein present in $S$. roseosporus that regulates the expression of many biosynthetic gene cluster and influences the organization of bacterial chromatin, but examples of influence the metabolites are less common.,9 Thus, we speculated that deletion of the Lsr2 in S. roseosporus might active or repress gene expression and produce novel compounds.

Herein, we report the isolation and structure elucidation of six new sulfur-containing compounds, pyrismycins A-F (1-6), with seven known analogues (7-13), from the Lsr2-deletion ( $\triangle$ Srlsr2) mutant strain of $S$. roseosporus. In this research, UPLCQTOF-MS/MS, a successful tool for dereplication purposes, ${ }^{10}$ was used to identify sulfur-containing metabolites from the $\Delta S r l s r 2$ strain, with present in the wild-type (WT) strain, and then used to guide the isolation work. The cytotoxic effects of isolated compounds on four clinically relevant human cancer cell lines, SGC7901 gastric carcinoma, MDA-MB-231 breast carcinoma, A549 lung carcinoma and HepG2 hepatocellular carcinoma, were evaluated (Fig. 1).

\section{Results and discussion}

UPLC-QTOF-MS analysis revealed 22 new peaks in the ethyl acetate extract of $\Delta S r l s r 2$ than were present in a similar extract of the WT strain (Fig. 2). This result indicated that deletion of the $L s r 2$ gene increased the number of secondary metabolites produced by this mutant strain. 14 peaks were identified as potential sulfur-containing derivatives, as supported by the molecular formula and fragment ions, and compared with the Streptomyces compounds previously indexed in the SciFinder database (Table $\mathrm{S} 1 \dagger)$.

Peak $9\left(t_{\mathrm{R}}=13.75 \mathrm{~min}\right)$ showed molecular ions at $\mathrm{m} / \mathrm{z}$ $291.0794[\mathrm{M}+\mathrm{H}]^{+}$and its molecular formula was determined to be $\mathrm{C}_{14} \mathrm{H}_{14} \mathrm{~N}_{2} \mathrm{O}_{3} \mathrm{~S}$ (Fig. 3). Tandem mass showed that the fragmentation of $[\mathrm{M}+\mathrm{H}]^{+}$precursor ion generated $[\mathrm{M}-\mathrm{OH}]^{+}$ion $(m / z 273.0695),\left[\mathrm{M}-\mathrm{OH}-\mathrm{CH}_{2}\right]^{+}$ion $(\mathrm{m} / z$ 259.0539), [M - OH $\left.\mathrm{OCH}_{3}\right]^{+}$ion $(m / z 243.0593)$ and fragment at $m / z 229.0446$. The fragment ion $\mathrm{m} / \mathrm{z} 229.0446$ further fragmented into fragment ion $\mathrm{m} / \mathrm{z} 204.0485$ and 181.0759. The transition from fragment ion $\mathrm{m} / \mathrm{z} 156.0802$ to 130.0660 indicated that it was a phenylpyridine derivative. ${ }^{\mathbf{1 1}, 12}$ Such a molecular formula and the basic structure units have not been found previously in Streptomyces metabolites. Similar fragmentation was also observed for peak 15. Thus, both peaks 9 and 15 were targeted as potentially new metabolites.

Peak $17\left(t_{\mathrm{R}}=20.31 \mathrm{~min}\right)$, peak $18\left(t_{\mathrm{R}}=20.43 \mathrm{~min}\right)$ and peak $19\left(t_{\mathrm{R}}=21.44 \mathrm{~min}\right)$ shared a same molecular formula of $\mathrm{C}_{13} \mathrm{H}_{14} \mathrm{~N}_{3} \mathrm{O}_{2} \mathrm{~S}$ with nearly same molecular ions at $m / z 276.0797$, 276.0794, and 276.0795 [M $+\mathrm{H}]^{+}$. They could be identified as isomeric compounds since their fragment pattern were different (Table S1†). The MS/MS spectra of peaks 18 and 17 are shown in Fig. $\mathrm{S} 1, \dagger$ with the molecular ions and the main fragment ions obtained under the high energy mode. The MS/MS spectra of peak 17 and peak 19 were nearly the same. The neutral loss of 33, 31, 28 and 26 mass units could account for the elimination of $-\mathrm{SH},-\mathrm{OCH}_{3},-\mathrm{CO}$ and $-\mathrm{CN}$, respectively. The product ions at $\mathrm{m} / \mathrm{z} 157.0761$ and 130.0652 were attributed to the characteristic fragment of dipyridyl derivatives, ${ }^{12}$ and the mass difference between peaks 17 and 18 was $\mathrm{m} / \mathrm{z} 182.0712$ and 185.0707 units for cyano-substituted dipyridyl and aldehydesubstituted dipyridyl, respectively, suggesting the existence of new sulfur-containing compounds. ${ }^{12}$

The similar investigation was applied to all 22 new peaks. As a result, eight target peaks $(5,9,15,16,17,18,20$ a and 21$)$ were considered as unknowns of interest. Combined with the HPLC analysis on the subfractions (Fig. S2 $\dagger$ ) of every separation process, the extract was separated by column chromatography and semi-preparative HPLC to obtain six new sulfur-containing compounds, pyrismycins A-F (1-6), together with seven known
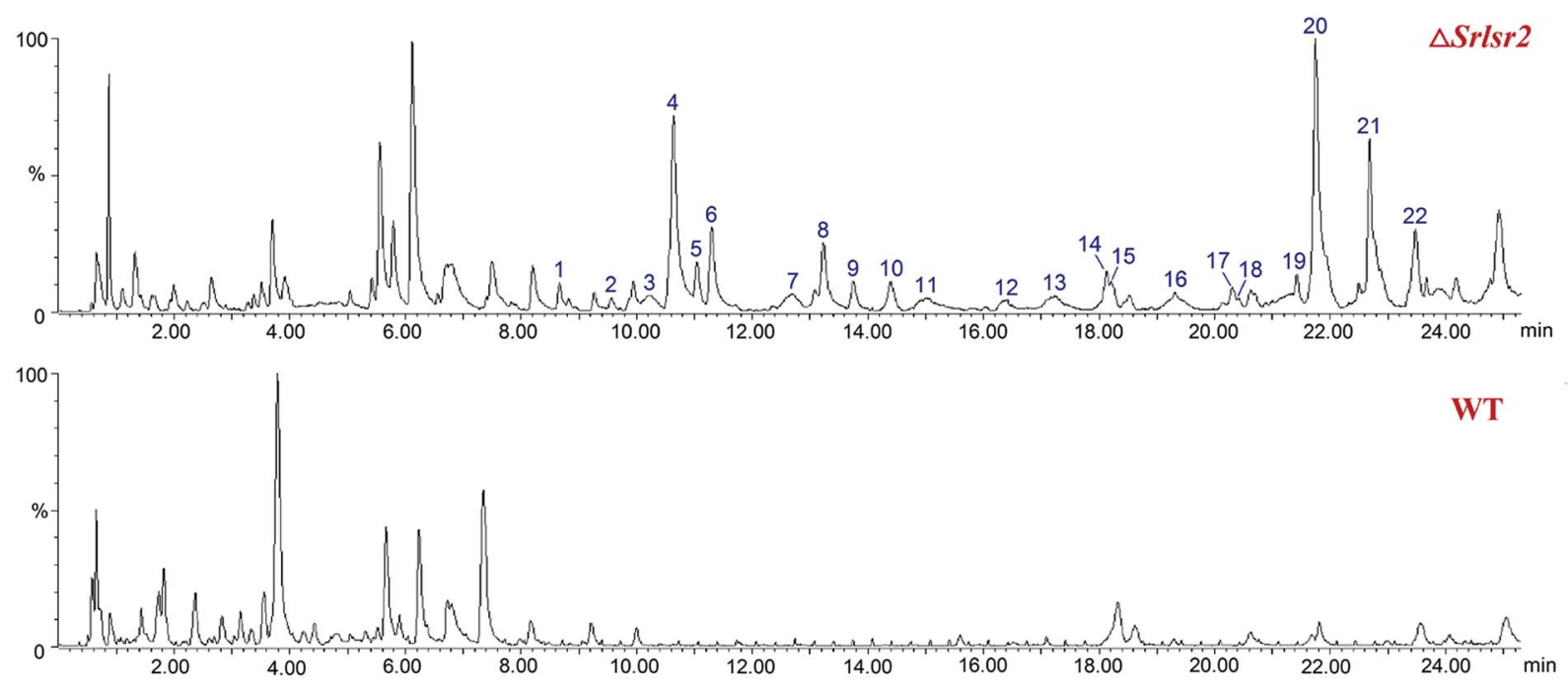

Fig. 2 UPLC-QTOF-MS profiles of the acetate extracts from $\Delta$ Srlsr2 (the upper diagram) and WT (the lower diagram) strains of S. roseosporus. 

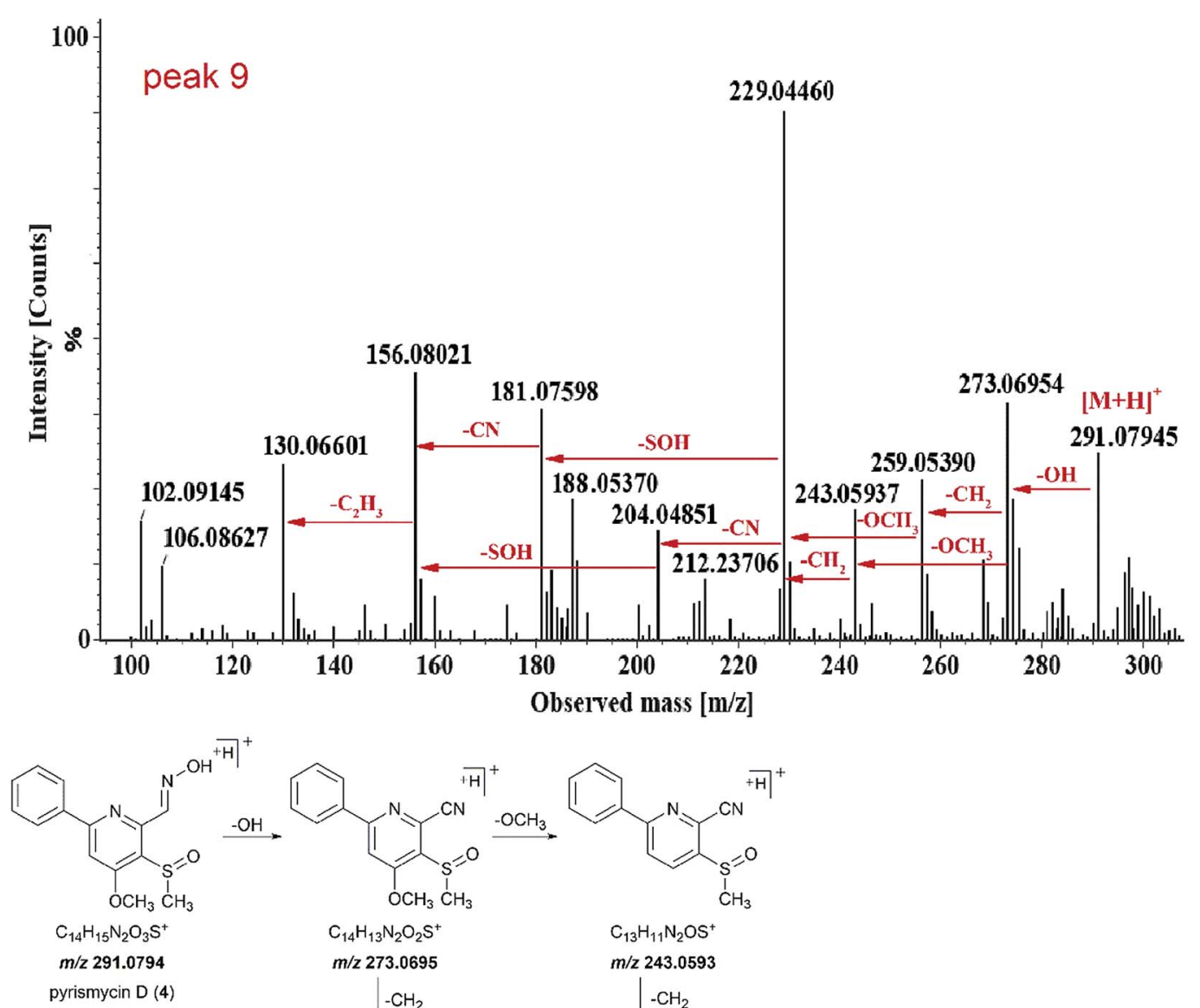<smiles></smiles>

$\mathrm{C}_{14} \mathrm{H}_{13} \mathrm{~N}_{2} \mathrm{O}_{2} \mathrm{~S}^{+}$

$m / 2273.0695$

$\mathrm{C}_{13} \mathrm{H}_{11} \mathrm{~N}_{2} \mathrm{OS}^{+}$

$m / 2291.0794$

$m / z 243.0593$

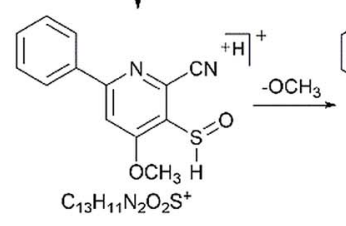

$m / 2259.0539$

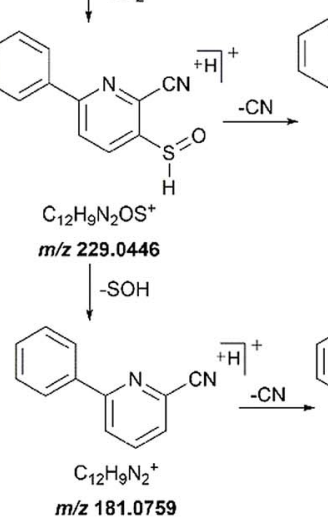<smiles>O=[SH]c1ccc(-c2ccccc2)nc1</smiles>

$m / 2204.0485$ $-\mathrm{SOH}$

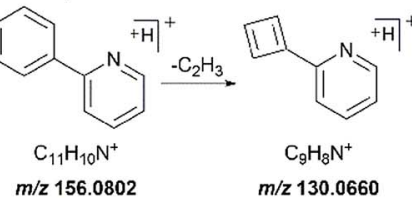

Fig. 3 HR-MS/MS spectra and proposed fragmentation pathway of peak 9 (4).

analogues 7-13. Their structures were elucidated by the means of HRESIMS, NMR data and single-crystal X-ray diffraction experiment.

Compound 1 (peak 17) was isolated as a yellow amorphous powder. Its molecular formula was assigned as $\mathrm{C}_{13} \mathrm{H}_{13} \mathrm{~N}_{3} \mathrm{O}_{2} \mathrm{~S}$ from HRESIMS peak at $m / z$ 276.0799 $[\mathrm{M}+\mathrm{H}]^{+}$(calcd for 276.0807), which requires nine degrees of unsaturation. The ${ }^{1} \mathrm{H}$ NMR spectrum showed signals for a proton spin system that included $\delta_{\mathrm{H}} 9.33\left(1 \mathrm{H}, \mathrm{d}, J=1.8 \mathrm{~Hz}, \mathrm{H}-2^{\prime}\right), 8.66(1 \mathrm{H}, \mathrm{dd}, J=4.8$, $\left.1.6 \mathrm{~Hz}, \mathrm{H}-6^{\prime}\right), 8.49\left(1 \mathrm{H}, \mathrm{dd}, J=6.9,4.8 \mathrm{~Hz}, \mathrm{H}-5^{\prime}\right)$ and $7.56(1 \mathrm{H}$, ddd, $J=6.9,1.8,1.6 \mathrm{~Hz}, \mathrm{H}-4^{\prime}$ ) (Table 1 ). The above data along with the observation of the ${ }^{13} \mathrm{C}$ NMR and DEPT resonances of one olefinic nonprotonated carbons at $\delta_{\mathrm{C}} 133.6\left(\mathrm{C}-3^{\prime}\right)$ and four olefinic methines carbons at $\delta_{\mathrm{C}} 150.1\left(\mathrm{C}-6^{\prime}\right), 148.0\left(\mathrm{C}-2^{\prime}\right), 134.2$ $\left(\mathrm{C}-5^{\prime}\right), 128.9\left(\mathrm{C}-4^{\prime}\right)$ indicated the presence of a mono-substituted pyridine ring (Table 2).${ }^{13}$ Similarly, the ${ }^{13} \mathrm{C}$ NMR and DEPT data further displayed four olefinic nonprotonated carbons at $\delta_{\mathrm{C}}$ 166.8 (C-4), 154.6 (C-2), 153.0 (C-6), 120.0 (C-5) and one olefinic methine carbons at $103.9(\mathrm{C}-3)$, along with a singlet at $\delta_{\mathrm{H}} 7.70$ $(1 \mathrm{H}, \mathrm{s}, \mathrm{H}-3)$, suggesting a tetra-substituted pyridine ring in $\mathbf{1 .}^{\mathbf{1 4}}$ The HMBC correlation between $\mathrm{H}-3$ with $\mathrm{C}-3^{\prime}$ was detected and confirmed the existence of 2,3'-dipyridyl moiety (Fig. 4). The ${ }^{1} \mathrm{H}$ NMR data also showed signals for one methoxyl group and one methyl group at $\delta_{\mathrm{H}} 4.08(3 \mathrm{H}, \mathrm{s}, \mathrm{H}-8)$ and $2.33(3 \mathrm{H}, \mathrm{s}, \mathrm{H}-9)$, respectively. The HMBC correlation between $\delta_{\mathrm{H}} 4.08$ with $\delta_{\mathrm{C}}$ 166.8 indicated that the methoxyl group was substituted at C-4. 
Table $1{ }^{1} \mathrm{H}$ NMR data of compounds $1-6(400 \mathrm{MHz}$, in DMSO, $\delta$ in ppm, $\mathrm{J}$ in $\mathrm{Hz}$ )

\begin{tabular}{|c|c|c|c|c|c|c|}
\hline Position & 1 & 2 & 3 & 4 & 5 & 6 \\
\hline 3 & $7.70, \mathrm{~s}$ & $8.03, \mathrm{~s}$ & $8.10, \mathrm{~s}$ & $7.68, \mathrm{~s}$ & $7.93, \mathrm{~s}$ & $8.03, \mathrm{~s}$ \\
\hline 7 & $8.72, \mathrm{~s}$ & & $3.91, \mathrm{~s}$ & $8.77, \mathrm{~s}$ & & $4.87, \mathrm{~d}(8.8)$ \\
\hline 9 & $2.33, \mathrm{~s}$ & $2.33, \mathrm{~s}$ & $2.35, \mathrm{~s}$ & $3.00, \mathrm{~s}$ & $3.06, \mathrm{~s}$ & $3.01, \mathrm{~s}$ \\
\hline $2^{\prime}$ & $9.33, \mathrm{~d}(1.8)$ & & & $\begin{array}{l}8.18, \mathrm{dd} \\
(7.7,1.8)\end{array}$ & $\begin{array}{l}8.19, \mathrm{dd} \\
(7.2,2.4)\end{array}$ & \\
\hline $5^{\prime}$ & 8.49, dd $(6.9,4.8)$ & 7.48, ddd $(6.8,4.8,1.2)$ & 7.51, ddd $(6.0,4.8,1.3)$ & $7.52, \mathrm{~m}$ & $7.57, \mathrm{~m}$ & 7.50, ddd $(6.8,4.9,1.3)$ \\
\hline $6^{\prime}$ & 8.66, dd $(4.8,1.6)$ & 8.70, ddd $(4.8,1.6,1.0)$ & 8.73, ddd $(4.8,2.0,1.2)$ & $\begin{array}{l}8.18, \mathrm{dd} \\
(7.7,1.8)\end{array}$ & $\begin{array}{l}8.19, \text { dd } \\
(7.2,2.4)\end{array}$ & 8.71, ddd $(4.9,1.6,1.2)$ \\
\hline $\mathrm{NOH}$ & $11.78, \mathrm{brs}$ & & & 11.93, brs & & \\
\hline $\begin{array}{l}-\mathrm{CONH}_{2} \\
7-\mathrm{OH}\end{array}$ & & 7.98, d (1.77) 7.57, s & & & & 5.35, brs \\
\hline
\end{tabular}

Taking into consideration the presence of one sulfur atom in the molecular formula of 1 and the chemical shifts of $\mathrm{H}-9, \mathrm{C}-9$ $\left(\delta_{\mathrm{C}}\right.$ 17.7), and $\mathrm{C}-5$, the existence of a methylthio group was established. The HMBC correlation between $\delta_{\mathrm{H}} 2.33$ with $\delta_{\mathrm{C}}$ 120.0 indicated that the methylthio group was located at C-5 position. Eight degrees of unsaturation were occupied by two pyridyl groups. Thus, the remaining unsaturation suggested that 1 may possess a double bond, which was consistent with the NMR data of the downfield carbon chemical shift at $\delta_{\mathrm{C}} 146.7$ $(\mathrm{C}-7)$ and one $\mathrm{N}-\mathrm{OH}$ proton signal at $\delta_{\mathrm{H}} 11.78(1 \mathrm{H}, \mathrm{brs})$. HMBC correlations of $\delta_{\mathrm{H}} 8.72(\mathrm{H}-7)$ with $\delta_{\mathrm{C}} 153.0$ and 120.0 confirmed the presence of an oxime group at C-6. The geometry of the oxime group was established by the comparison of the chemical shift of the $\mathrm{N}-\mathrm{OH}$ signal with those in the known bipyridine analogue, SF2738 A (7). ${ }^{\mathbf{1 4 , 1 5}}$ Thus, compound 1 was characterized as (E)-4-methoxy-5-(methylthio)-[2,3'-bipyridine]-6carboxaldehyde oxime and named pyrismycin $\mathrm{A}$.

Compound 2 (peak 18) was isolated as yellow amorphous powder. Its molecular formula was determined to be $\mathrm{C}_{13} \mathrm{H}_{13} \mathrm{~N}_{3} \mathrm{O}_{2} \mathrm{~S}$ based on the observation of an $[\mathrm{M}+\mathrm{Na}]^{+}$ion at $\mathrm{m} / z$ 298.0619 (calcd for 298.0626) in its positive ion mode HRESIMS spectrum. Similar to the known compound $10,{ }^{15}$ whose structure was elucidated by a single-crystal X-ray diffraction experiment (Fig. S3 $\dagger$ ), 2 is also a $2,2^{\prime}$-dipyridyl derivative, as shown by the presence of a proton spin system including $\delta_{\mathrm{H}} 8.70(1 \mathrm{H}, \mathrm{ddd}, J=$ 4.8, 1.6, 1.0, H-6'), $8.40\left(1 \mathrm{H}, \mathrm{ddd}, J=8.0,1.2,1.0, \mathrm{H}-3^{\prime}\right), 7.94(1 \mathrm{H}$, $\left.\mathrm{ddd}, J=8.0,6.8,1.6, \mathrm{H}-4^{\prime}\right)$ and $7.48(1 \mathrm{H}, \mathrm{ddd}, J=6.8,4.8,1.2, \mathrm{H}-$ $\left.5^{\prime}\right)$, a singlet signal at $\delta_{\mathrm{H}} 8.03(1 \mathrm{H}, \mathrm{s}, \mathrm{H}-3)$ (Table 1), five olefinic nonprotonated carbons at $\delta_{\mathrm{C}} 166.5$ (C-4), 158.0 (C-2), 155.3 (C-2'), 154.2 (C-6) and 118.5 (C-5), and five olefinic methine carbons at $\delta_{\mathrm{C}} 149.1\left(\mathrm{C}^{\prime} 6^{\prime}\right), 137.2\left(\mathrm{C}-4^{\prime}\right), 124.5\left(\mathrm{C}-5^{\prime}\right), 120.9\left(\mathrm{C}-3^{\prime}\right)$ and $103.2(\mathrm{C}-$ 3) (Table 2). The HMBC correlation of $\delta_{\mathrm{H}} 8.03$ with $\delta_{\mathrm{C}} 155.3$ further confirmed the existence of a 2,2'-dipyridyl skeleton (Fig. 4). A methoxyl group at $\delta_{\mathrm{H}} 4.06(3 \mathrm{H}, \mathrm{s}, \mathrm{H}-8)$ and $\delta_{\mathrm{C}} 56.2(\mathrm{C}-8)$, a methylthio group at $\delta_{\mathrm{H}} 2.33(3 \mathrm{H}, \mathrm{s}, \mathrm{H}-9)$ and $\delta_{\mathrm{C}} 17.4(\mathrm{C}-9)$ and an amide group at $\delta_{\mathrm{H}} 7.98(1 \mathrm{H}, \mathrm{d}, J=1.77 \mathrm{~Hz}), 7.57(1 \mathrm{H}, \mathrm{s})$ and $\delta_{\mathrm{C}}$ 168.5 (C-7) were observed in NMR data of 2. Cross peaks of $\delta_{\mathrm{H}}$ 4.06 with $\delta_{\mathrm{C}} 166.5$ and $\delta_{\mathrm{H}} 2.33$ with $\delta_{\mathrm{C}} 118.5$ in HMBC indicated that the methoxyl group and methylthio group were located at C-4 and C-5, respectively. Thus, the amide group was substituted at C6. 2 was characterized as 4-methoxy-5-(methylthio)-[2,2'bipyridine]-6-carboxamide and named pyrismycin B.

Compound 3 (peak 5) was isolated as yellow amorphous powder. Its molecular formula was determined as $\mathrm{C}_{13} \mathrm{H}_{14} \mathrm{~N}_{2} \mathrm{O}_{2} \mathrm{~S}$

Table $2{ }^{13} \mathrm{C}$ NMR data of compounds $1-6(100 \mathrm{MHz}$, in DMSO, $\delta$ in ppm)

\begin{tabular}{|c|c|c|c|c|c|c|}
\hline Position & 1 & 2 & 3 & 4 & 5 & 6 \\
\hline 2 & 154.6, C & 158.0, C & $156.2, \mathrm{C}$ & 159.4, C & $161.2, \mathrm{C}$ & $157.7, \mathrm{C}$ \\
\hline 3 & 103.9, CH & $103.2, \mathrm{CH}$ & $104.3, \mathrm{CH}$ & 104.1, CH & $107.5, \mathrm{CH}$ & 103.3, CH \\
\hline 4 & $166.8, \mathrm{C}$ & 166.5, C & 167.0, C & 165.0, C & 164.1, C & $164.6, \mathrm{C}$ \\
\hline 5 & 120.0, C & 118.5, C & 117.7, C & 126.2, C & 132.3, C & 126.3, C \\
\hline 6 & $153.0, \mathrm{C}$ & 154.2, C & 167.0, C & $150.4, \mathrm{C}$ & 136.3, C & 159.8, C \\
\hline 7 & 146.7, CH & $168.5, \mathrm{C}$ & $52.5, \mathrm{CH}_{3}$ & 146.1, CH & $115.0, \mathrm{C}$ & $62.8, \mathrm{CH}_{2}$ \\
\hline 8 & $56.6, \mathrm{CH}_{3}$ & $56.2, \mathrm{CH}_{3}$ & $56.5, \mathrm{CH}_{3}$ & $56.7, \mathrm{CH}_{3}$ & $57.5, \mathrm{CH}_{3}$ & $56.5, \mathrm{CH}_{3}$ \\
\hline 9 & $17.7, \mathrm{CH}_{3}$ & $17.4, \mathrm{CH}_{3}$ & $17.4, \mathrm{CH}_{3}$ & $39.5, \mathrm{CH}_{3}$ & $39.5, \mathrm{CH}_{3}$ & $39.0, \mathrm{CH}_{3}$ \\
\hline $1^{\prime}$ & & & & $137.5, \mathrm{C}$ & $130.5, \mathrm{C}$ & \\
\hline $2^{\prime}$ & 148.0, CH & 155.3, C & 153.6, C & 127.1, CH & $127.4, \mathrm{CH}$ & 153.9, C \\
\hline $3^{\prime}$ & 133.6, C & $120.9, \mathrm{CH}$ & $120.7, \mathrm{CH}$ & 128.6, CH & $128.9, \mathrm{CH}$ & $121.2, \mathrm{CH}$ \\
\hline $4^{\prime}$ & $128.9, \mathrm{CH}$ & $137.2, \mathrm{CH}$ & $137.8, \mathrm{CH}$ & $130.0, \mathrm{CH}$ & $130.7, \mathrm{CH}$ & $137.3, \mathrm{CH}$ \\
\hline $5^{\prime}$ & $134.2, \mathrm{CH}$ & $124.5, \mathrm{CH}$ & 125.1, CH & 128.6, CH & $128.9, \mathrm{CH}$ & $124.9, \mathrm{CH}$ \\
\hline $6^{\prime}$ & $150.1, \mathrm{CH}$ & 149.1, CH & 149.6, CH & 127.1, CH & $127.4, \mathrm{CH}$ & $149.2, \mathrm{CH}$ \\
\hline
\end{tabular}




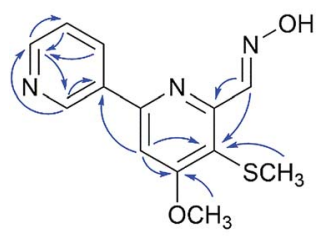

1

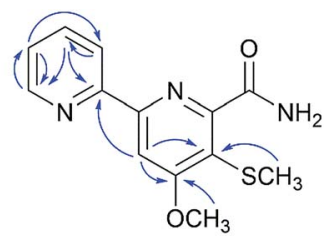

2

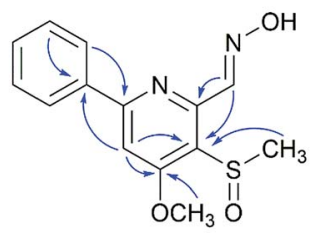

4

Fig. 4 Key HMBC correlations of 1, 2 and 4 .

according to an $[\mathrm{M}+\mathrm{Na}]^{+}$ion at $m / z 285.0666$ (calcd for 285.0674) in its positive ion mode HRESIMS spectrum. Comparison of the ${ }^{13} \mathrm{C}$ and ${ }^{1} \mathrm{H}$ NMR data of 3 with 2 revealed extensive similarities, except that the methoxy signals at $\delta_{\mathrm{H}} 3.91$ $(3 \mathrm{H}, \mathrm{s}, \mathrm{H}-7)$ and $\delta_{\mathrm{C}} 52.5$ (C-7) in 3 was replaced by an amide group $\left(\delta_{\mathrm{H}} 7.98\right.$ and $\left.7.57, \delta_{\mathrm{C}} 168.5\right)$ in 2 . The HMBC correlation of $\delta_{\mathrm{H}} 3.91$ with $\delta_{\mathrm{C}} 167.0(\mathrm{C}-6)$ indicated that the methoxyl group was substituted at C- 6 . Thus, compound 3 was characterized as 4,6-dimethoxy-5-(methylthio)-2,2'-bipyridine and named pyrismycin $\mathrm{C}$.

Compound 4 (peak 9) was isolated as yellow amorphous powder. The molecular formula was determined to be $\mathrm{C}_{14} \mathrm{H}_{14} \mathrm{~N}_{2} \mathrm{O}_{3} \mathrm{~S}$ from the $[\mathrm{M}+\mathrm{H}]^{+}$peak at $\mathrm{m} / z 291.0793$ (calcd for 291.0803) in its positive ion mode HRESIMS spectrum. The NMR data of 4 were similar to pyrisulfoxin A (11), previously isolated from Streptomyces californicus BS-75. ${ }^{16}$ Both compounds shared the same tetra-substituted pyridine ring as revealed by the presence at $\delta_{\mathrm{C}} 165.0(\mathrm{C}-4), 159.4(\mathrm{C}-2), 150.4(\mathrm{C}-$ 6), 126.2 (C-5), 104.1 (C-3) (Table 2). Moreover, a methoxyl group at $\delta_{\mathrm{H}} 4.08(3 \mathrm{H}, \mathrm{s}, \mathrm{H}-8)$, a methylsulfoxide group at $\delta_{\mathrm{H}} 3.00(3 \mathrm{H}, \mathrm{s}$, $\mathrm{H}-9)$ and an oxime group at $\delta_{\mathrm{H}} 8.77(1 \mathrm{H}, \mathrm{s}, \mathrm{H}-7)$ (Table 1) were also analogous of $\mathbf{1 1}$ and substituted at C-4, C- 5 and C- 6 based on the HMBC correlations of $\delta_{\mathrm{H}} 4.08$ with $\delta_{\mathrm{C}} 165.0, \delta_{\mathrm{H}} 3.00$ with $\delta_{\mathrm{C}} 126.2$ and $\delta_{\mathrm{H}} 8.77(1 \mathrm{H}, \mathrm{s}, \mathrm{H}-7)$ with $\delta_{\mathrm{C}} 150.4$, respectively (Fig. 4). The difference lies on the mono-substituted pyridine ring in $\mathbf{1 1}$ and the mono-substituted phenyl ring in $\mathbf{4}$, as shown by the protons at $\delta_{\mathrm{H}} 8.18$ (each $1 \mathrm{H}, \mathrm{dd}, J=7.7,1.8 \mathrm{~Hz}, \mathrm{H}^{\prime}{ }^{\prime}, 6^{\prime}$ ) and 7.51-7.53 $\left(3 \mathrm{H}, \mathrm{m}, \mathrm{H}-3^{\prime}, 4^{\prime}, 5^{\prime}\right)$, as well as the aromatic carbon signals at $\delta_{\mathrm{C}} 137.5\left(\mathrm{C}-1^{\prime}\right), 130.0\left(\mathrm{C}-4^{\prime}\right), 128.6 \times 2\left(\mathrm{C}-3^{\prime}, 5^{\prime}\right)$ and $127.1 \times 2\left(\mathrm{C}-2^{\prime}, 6^{\prime}\right)$. The HMBC correlations of $\delta_{\mathrm{H}} 7.68(1 \mathrm{H}, \mathrm{s}, \mathrm{H}-$ 3 ) and 7.52 (each $\left.1 \mathrm{H}, \mathrm{m}, \mathrm{H}-3^{\prime} / 4^{\prime} / 5^{\prime}\right)$ with $\mathrm{C}-1^{\prime}$ and $8.18\left(\mathrm{H}-2^{\prime}\right)$ with C-2 confirmed the pyridine ring was connected at C-2 (Fig. 4). Thus, 4 was characterized as (E)-4-methoxy-5-(methylsulfinyl)-6phenylpicolinaldehyde oxime and named pyrismycin D.

Compound 5 (peak 15) was isolated as yellow amorphous powder. Its HRESIMS data exhibited a $[\mathrm{M}+\mathrm{Na}]^{+}$ion at $\mathrm{m} / z$ 295.0511 (calcd for 295.0517) corresponded to a molecular formula of $\mathrm{C}_{14} \mathrm{H}_{12} \mathrm{~N}_{2} \mathrm{O}_{2} \mathrm{~S}$ and revealed eleven degrees of unsaturation. The UV and NMR data features of compound 5 were very similar to those of $\mathbf{4}$, except for the substitution of a cyano group $\left(\delta_{\mathrm{C}} 115.0\right)$ at C-6 in 5, which was also supported by the existence of two nitrogen atom in its molecular formula, instead of an oxime group in $\mathbf{4}$. Thus, compound 5 was characterized as 4-methoxy-5-(methylsulfinyl)-6-phenylpicolinonitrile and named pyrismycin E.

Compound 6 (peak 16) was isolated as yellow amorphous powder. Its molecular formula was assigned as $\mathrm{C}_{13} \mathrm{H}_{14} \mathrm{~N}_{2} \mathrm{O}_{3} \mathrm{~S}$ on the basis of a $[\mathrm{M}+\mathrm{Na}]^{+}$ion at $m / z 301.0620$ (calcd for 301.0623) in its positive ion mode HRESIMS spectrum. The ${ }^{1} \mathrm{H}$ and ${ }^{13} \mathrm{C}$ NMR data of 6 indicated it is an analogue of $\mathbf{1 1 .}{ }^{\mathbf{1 4}}$ Comparison of the NMR data of $\mathbf{6}$ with those of $\mathbf{1 1}$ showed the absence of the oxime group, and the presence of a methylol group at $\delta_{\mathrm{C}} 62.8(\mathrm{C}-$ $7), \delta_{\mathrm{H}} 4.87(2 \mathrm{H}, \mathrm{d}, J=8.8 \mathrm{~Hz}, \mathrm{H}-7)$ and $5.35(1 \mathrm{H}$, brs $)$ in 6 . This methylol group was positioned at C-6 based on the HMBC correlation of $\delta_{\mathrm{H}} 4.87$ with $\delta_{\mathrm{C}} 159.8(\mathrm{C}-6)$. Thus, 6 was characterized as (4-methoxy-5-(methylsulfinyl)-[2,2'-bipyridin]-6-yl) methanol and named pyrismycin $\mathrm{F}$.

The structures of compounds 7-13 were identified as the previously reported natural compounds, SF2738A (7, peak 19), ${ }^{\mathbf{1 4}}$ SF2738C (8, peak 6), ${ }^{13}$ SF2738D (9, peak 4), ${ }^{15}$ SF2738E (10, peak 11), ${ }^{15}$ pyrisulfoxin A $(\mathbf{1 1}$, peak 7$),{ }^{16}$ pyrisulfoxin B $(12 \text {, peak } 14)^{16}$ and caerulomycin A (13, peak 12), ${ }^{11}$ by a comparison of their ${ }^{1} \mathrm{H}$ and ${ }^{13} \mathrm{C}$ NMR data with the literature.

All isolates (1-13) were evaluated for cytotoxicity against the SGC7901, MDA-MB-231, A549 and HepG2 cell lines (ESI Experimental section $\dagger$ ). Compounds 7, 9 and 11 displayed measurable $\mathrm{IC}_{50}$ values, but others showed no cytotoxicity (Table S2 $\dagger$ ). The most potent one, SF2738A (7), showed cytotoxic activities against SGC7901 with $\mathrm{IC}_{50}$ value of $1.7 \mu \mathrm{M}$, HepG2 with $\mathrm{IC}_{50}$ value of $5.8 \mu \mathrm{M}$ and MDA-MB-231 with $\mathrm{IC}_{50}$ value of $6.3 \mu \mathrm{M}$, while pyrisulfoxin A (11) showed distinct cytotoxic activity for HepG2 with $\mathrm{IC}_{50}$ value of $7.2 \mu \mathrm{M}$. A gross structure-activity relationships (SAR) for this class of compounds was discussed as follows: (1) the 2,2'-dipyridyl moiety may be crucial for the cytotoxicity since pyrismycin A (1), with a greatly similar structures with its isomer 7 except for the 2,3'-dipyridyl moiety, has no displayed deemed cytotoxic for any of the cell lines used. (2) The absence of oxime group in C-7 may remarkably reduce the cytotoxicity. Compound 3 with the methoxyl group in place of the oxime group of 7 significantly decreased the inhibitory activities, which also can be observed in the other analogues of 2 and 8-10. (3) As compared with 7, the presence of a methylsulfoxide group at C-5 in $\mathbf{1 1}$ may obviously improve the selectivity of the types of cancer cell lines.

\section{Experimental}

\section{General experimental procedures}

UV spectra were recorded on a Shimadzu UV-260 spectrophotometer (Shimadzu Corp., Japan) in absolute methanol ( $\mathrm{MeOH})$. IR spectra were record as $\mathrm{KBr}$ pellets on the Avatar 360 E.S.P spectrophotometer (Thermo Nicolet Co. Boston, MA, USA). NMR data were acquired with a Bruker Avance 400 spectrometer using solvent signals (DMSO; $\delta_{\mathrm{H}} 2.50 / \delta_{\mathrm{C}} 39.52$ ) as reference. UPLC-QTOF-MS was operated using an Acquity UPLC system (Waters Corp., Milfoed, USA) with a QTOF-MS (XEVO-G2 QTOF, Waters MS Technologies, Manchester, UK), controlled by 
MassLynx V4.1 software. Semipreparative reversed-phase HPLC separation was performed on a Shimadzu LC-6AD instrument packed with a YMS-pack ODS-A column $(5 \mu \mathrm{m}, 250 \times 10 \mathrm{~mm})$. $X$-ray diffraction was realized on a Bruker D8 QUEST X-ray single crystal diffractometer using Mo $\mathrm{K} \alpha$ radiation $(\lambda=0.71073)$. Sephadex LH-20 (GE Healthcare Bio-Sciences AB, Uppsala, Sweden), MCI Gel CHP 20/P120 (Mitsubishi Chemical Corp., Japan) and ODS-A 12 nm S-50 $\mu \mathrm{m}$ (YMC Co., Ltd, Japan) were used for column chromatography, respectively. Human gastric carcinoma SGC7901, breast carcinoma MDA-MB-231, lung carcinoma A549 and hepatocellular carcinoma HepG2 were obtained from Shanghai Institutes for Biological Sciences, Chinese Academy of Sciences.

\section{Bacteria material}

S. roseosporus Lsr2-deletion mutant strain ( $\Delta S r l s r 2)$ and WT strain were obtained from Dr Guojian Liao, College of Pharmaceutical Sciences, Southwest University, China. The voucher specimens (no. 2016102901 and 2016102902) were deposited in the College of Pharmaceutical Sciences, Southwest University, China.

\section{Fermentation and isolation}

The $\Delta S r l s r 2$ strain was grown on PDA plates at $28{ }^{\circ} \mathrm{C}$ for 6 days. Then the agar plate were cut into small pieces and inoculated into sterilized liquid potato dextrose broth medium in Erlenmeyer flasks for further incubation at $28{ }^{\circ} \mathrm{C}$ on a rotary shaker at $170 \mathrm{rpm}$ for 6 days. The fermented whole broth was filtered to remove the mycelia, and the broth was then extracted four times with ethyl acetate to get about $60 \mathrm{~L}$ of extract solution. Then solvent was evaporated under reduced pressure to afford a crude residue $(20.9 \mathrm{~g})$. The extract was applied to an ODS column eluted with water, $30 \%, 40 \%, 50 \%, 60 \%, 70 \%, 80 \%$, $100 \% \mathrm{MeOH}$ and concentrated, affording 4 combined fractions (Fr.1-Fr.4). Fr.3 was then separately isolated on MCI gel column and eluted with $\mathrm{MeOH}-\mathrm{H}_{2} \mathrm{O}$ to obtain 3 subfractions Fr.3.1 to Fr.3.3. Fr.3.1 was separated by semipreparative HPLC, using a gradient of $75-92 \% \mathrm{MeOH}$ in $\mathrm{H}_{2} \mathrm{O}$ over $47 \mathrm{~min}$, to give 3 $\left(2.5 \mathrm{mg}, t_{\mathrm{R}}=36 \mathrm{~min}\right)$ and $9\left(1.6 \mathrm{mg}, t_{\mathrm{R}}=23 \mathrm{~min}\right)$. Fr.3.2 was separated over Sephadex LH-20 column chromatography, using $\mathrm{CH}_{2} \mathrm{Cl}_{2}-\mathrm{MeOH}(1: 3)$ as an eluent, to yield two subfractions (Fr.3.2.1 and Fr.3.2.2). Fr.3.2.1 was further purified using semipreparative $\mathrm{HPLC}$, eluting with a $\mathrm{MeOH}-\mathrm{H}_{2} \mathrm{O}(2: 3)$ over $88 \mathrm{~min}$, to give $4\left(1.8 \mathrm{mg}, t_{\mathrm{R}}=75 \mathrm{~min}\right), 8\left(3.5 \mathrm{mg}, t_{\mathrm{R}}=32 \mathrm{~min}\right)$ and $11\left(2.5 \mathrm{mg}, t_{\mathrm{R}}=36 \mathrm{~min}\right)$. Similarly, Fr.3.2.2 was subjected to semipreparative HPLC, eluted with $33 \% \mathrm{MeOH}$ in $\mathrm{H}_{2} \mathrm{O}$ over $63 \mathrm{~min}$, to provide $5\left(1.0 \mathrm{mg}, t_{\mathrm{R}}=54 \mathrm{~min}\right), 10\left(2.7 \mathrm{mg}, t_{\mathrm{R}}=27\right.$ $\min ), 12\left(2.2 \mathrm{mg}, t_{\mathrm{R}}=58 \mathrm{~min}\right)$ and $13\left(1.2 \mathrm{mg}, t_{\mathrm{R}}=33 \mathrm{~min}\right)$. Fr.3.3 was chromatographed by semipreparative HPLC, eluting with a step gradient of $32-60 \% \mathrm{MeOH}$ in $\mathrm{H}_{2} \mathrm{O}$ over $93 \mathrm{~min}$, giving 1 (2.0 mg, $\left.t_{\mathrm{R}}=64 \mathrm{~min}\right), 2\left(1.8 \mathrm{mg}, t_{\mathrm{R}}=80 \mathrm{~min}\right), 6(2.1 \mathrm{mg}$, $\left.t_{\mathrm{R}}=39 \mathrm{~min}\right)$ and $7\left(3.0 \mathrm{mg}, t_{\mathrm{R}}=85 \mathrm{~min}\right)$.

\section{Structure characterization}

Pyrismycin A (1). Yellow, amorphous powder; UV (MeOH) $\lambda_{\max }(\log \varepsilon) 239$ (3.9) nm; IR (KBr) $\nu_{\max }$ 3431, 2929, 2872, 2364,
1631, 1568, 1377, 1300, 1232, 1128, 1018, 871, 790, 758, 692 $\mathrm{cm}^{-1} ;{ }^{1} \mathrm{H}$ and ${ }^{13} \mathrm{C}$ NMR data see Tables 1 and 2; HRESI $(+)$ MS m/ $z 276.0799$ (calcd for 276.0807).

Pyrismycin B (2). Yellow, amorphous powder; UV (MeOH) $\lambda_{\max }(\log \varepsilon) 285$ (3.8) nm; IR (KBr) $\nu_{\max } 3441,3361,2926,2858$, 1662, 1570, 1452, 1375, 1217, 1124, 1045, 854, 786, 738, 661 $\mathrm{cm}^{-1} ;{ }^{1} \mathrm{H}$ and ${ }^{13} \mathrm{C}$ NMR data see Tables 1 and 2; HRESI $(+) \mathrm{MS} m /$ $z 298.0619$ (calcd for 298.0626).

Pyrismycin C (3). Yellow, amorphous powder; UV (MeOH) $\lambda_{\text {max }}(\log \varepsilon) 284$ (3.6) nm; IR (KBr) $\nu_{\max } 3433,2933,1724,1647$, 1635, 1598, 1438, 1369, 1224, 1033, 781, $692 \mathrm{~cm}^{-1} ;{ }^{1} \mathrm{H}$ and ${ }^{13} \mathrm{C}$ NMR data see Tables 1 and 2; HRESI (+) MS $m / z 285.0666$ (calcd for 285.0674).

Pyrismycin D (4). Yellow, amorphous powder; UV (MeOH) $\lambda_{\max }(\log \varepsilon) 247$ (3.8) nm; ${ }^{1} \mathrm{H}$ and ${ }^{13} \mathrm{C}$ NMR data see Tables 1 and 2; HRESI (+) MS $m / z 291.0793$ (calcd for 291.0803).

Pyrismycin E (5). Yellow, amorphous powder; UV (MeOH) $\lambda_{\text {max }}(\log \varepsilon) 243$ (3.8) nm, 279 (3.7) nm; ${ }^{1} \mathrm{H}$ and ${ }^{13} \mathrm{C}$ NMR data see Tables 1 and 2; HRESI (+) MS m/z 295.0511 (calcd for 295.0517).

Pyrismycin F (6). Yellow, amorphous powder; UV (MeOH) $\lambda_{\max }(\log \varepsilon) 281$ (4.1) nm; IR (KBr) $\nu_{\max } 3441,3346,2987,2926$, 1564, 1421, 1271, 1217, 1028, 945, 881, 788, 686, 621, $540 \mathrm{~cm}^{-1}$; ${ }^{1} \mathrm{H}$ and ${ }^{13} \mathrm{C}$ NMR data see Tables 1 and 2; HRESI $(+)$ MS $m / z$ 301.0620 (calcd for 301.0623).

X-ray crystallographic data for $10 . \mathrm{C}_{15} \mathrm{H}_{17} \mathrm{~N}_{3} \mathrm{O}_{2} \mathrm{~S}$, prism crystals from $\mathrm{CHCl}_{3} / \mathrm{MeOH}, M=303.38$, monoclinic, $a=11.2581$ (2) $\AA, b=28.6822(10) \AA, c=19.2173(5) \AA ⿻$ ㅇ, $\beta=103.658(2)^{\circ}, V=$ 6029.9(3) $\AA^{3}, T=293(2) \mathrm{K}$, space group $P 2_{1} / n$ (\#14), $Z=4, \mu$ (Mo $\mathrm{K} \alpha)=0.223 \mathrm{~mm}^{-1}, 27243$ reflections measured, 13668 independent reflections $\left(R_{\text {int }}=0.0224\right)$. The final $R_{1}$ values were $0.0536(I>2 \sigma(I))$, and the final $\mathrm{w} R\left(F^{2}\right)$ values were 0.1460 (all data). The goodness of fit on $F^{2}$ was 1.057. Crystallographic data were deposited with the Cambridge Crystallographic Data Centre (deposition code: CCDC 1533762).†

\section{UPLC-QTOF-MS conditions}

Chromatographic separation was performed with a $2.1 \times 50$ mm i.d., 1.7 $\mu \mathrm{m}$ UPLC BEH C18 reversed-phase column and kept at a temperature of $40{ }^{\circ} \mathrm{C}$. The mobile phase consisted of water (A) and acetonitrile (B). The linear gradient elution was performed as follows: $0-0.4 \mathrm{~min}, 5 \% \mathrm{~B}$; 0.4-20 $\mathrm{min}, 5-45 \% \mathrm{~B}$; 20-24 min, 45-65\% B; 24-26 min, 65-76\% B; 26-35 min, 76$100 \% \mathrm{~B} ; 35-36 \mathrm{~min}, 100-0.5 \% \mathrm{~B} ; 36-38 \mathrm{~min}, 0.5-0.5 \% \mathrm{~B}$. A flow rate of $0.4 \mathrm{~mL} \mathrm{~min}^{-1}$ was employed for elution, and the injected sample volume was set at $2 \mu \mathrm{L}$. Mass spectrometry was recorded using a Xevo G2 QTOF equipped with an ESI source and MS full scanning was conducted in positive ion modes over the range $\mathrm{m} / \mathrm{z} 100-1000 \mathrm{Da}$, with a scan time of $0.2 \mathrm{~s}$. The capillary voltages were set at $3000 \mathrm{~V}$ and the cone voltage was $40 \mathrm{~V}$. Nitrogen gas was used both for the nebulizer and in desolvation. The desolvation and cone gas flow rates were 800 and $50 \mathrm{~L} \mathrm{~h}^{-1}$, respectively. The desolvation temperature was $450{ }^{\circ} \mathrm{C}$, and the source temperature was $120{ }^{\circ} \mathrm{C}$. The tandem MS data were acquired in the positive mode with a range of $m / z 100-1000 \mathrm{Da}$, and the low energy was set as $6 \mathrm{~V}$, while the high energy was ramped from 20 to $40 \mathrm{~V}$. The cone voltage was set as $40 \mathrm{~V}$. 


\section{Conclusions}

The combination of UPLC-QTOF-MS/MS and HPLC analysis is an effective chemical dereplication method for structural analysis of compounds and rapid isolation of unknowns of interest in $\Delta S r l s r 2$ strain, whereas the conventional separation often requires a great deal of work to obtain the desired compounds. Pyrisulfoxins A-F (1-6), six sulfur-containing metabolites have not yet been described in the literature, and seven known analogues (7-13) were isolated from the $4 S r l s r 2$ strain. Among these compounds tested for cytotoxicity, SF2738A (7) showed the highest activity for SGC7901 cell lines, and pyrisulfoxin A (11) showed moderate cytotoxic for HepG2 cell lines. It was suggested that the 2,2'-dipyridyl moiety may be crucial for the cytotoxicity, and the absence of oxime group in C-7 may remarkably reduce the cytotoxicity.

This is the first report that deletion of the global regulator Lsr2 in S. roseosporus upregulated the expression of biosynthetic gene cluster and produced new compounds, pyrisulfoxins A-F (1-6). And this further demonstrated that deletion of the global regulator Lsr2 is an effective approach to produce new secondary metabolites.

\section{Conflict of interest}

There are no conflicts of interest to declare.

\section{Acknowledgements}

This work was supported by the National High Technology Research and Development Program of China (2011AA100607), Fundamental Research Funds for the Central Universities (XDJK2014A008), and National Natural Science Foundation of China (81602987).

\section{References}

1 M. Nett, H. Ikeda and B. S. Moore, Nat. Prod. Rep., 2009, 26, 1362-1384.

2 J. A. Worrall and E. Vijgenboom, Nat. Prod. Rep., 2010, 27, 742-756.

3 C. Christophersen and U. Anthoni, J. Sulfur Chem., 1986, 4, 365-442.

4 A. L. Demain and S. Sanchez, J. Antibiot., 2009, 62, 5-16.

5 L. Shen, master thesis, Southwest University, 2016.

6 N. Ziemert, M. Alanjary and T. Weber, Nat. Prod. Rep., 2016, 33, 988-1005.

7 P. J. Rutledge and G. L. Challis, Nat. Rev. Microbiol., 2015, 13, 509-522.

8 B. R. Gordon, R. Imperial, L. Wang, W. W. Navarre and J. Liu, J. Bacteriol., 2008, 190, 7052-7059.

9 H. M. Ashmead, L. Negron, K. Webster, V. Arcus and J. A. Gerrard, Biopolymers, 2014, 103, 261-270.

10 S. P. Gaudencio and F. Pereira, Nat. Prod. Rep., 2015, 32, 779810.

11 S. H. Kim, H. Ko, H. S. Bang, S. H. Park, D. G. Kim, H. C. Kwon, S. Y. Kim, J. Shin and D. C. Oh, Bioorg. Med. Chem. Lett., 2011, 21, 5715-5718.

12 J. Regueiro, A. Giri and T. Wenzl, Anal. Chem., 2016, 88, 6500-6508.

13 F. Trecourt, B. Gervais, O. Mongin, C. L. Gal, F. Mongin and G. Queguiner, J. Org. Chem., 1998, 63, 2892-2897.

14 K. Shindo, Y. Yamagishi, Y. Okada and H. Kawai, J. Antibiot., 1994, 47, 1072-1074.

15 S. Gomi, S. Amano, E. Sato, S. Miyadoh and Y. Kodama, J. Antibiot., 1994, 47, 1385-1394.

16 N. Tsuge, K. Furihata, K. Shin-Ya, Y. Hayakawa and H. Seto, J. Antibiot., 1999, 52, 505-507. 